\title{
Piotra Lenartowicza filozofia a nauki matematyczne
}

\author{
Robert Janusz \\ Instytut Filozofii, Akademia Ignatianum w Krakowie \\ ul. Kopernika 26, 31-501 Kraków \\ rjanusz@specola.va • ORCID 0000-0001-9146-9274
}

\section{Streszczenie}

W artykule omawiana jest filozofia przyrody Piotra Lenartowicza SJ w kontekście matematycznego przyrodoznawstwa. Refleksje filozoficzne dotyczące biologii Lenartowicz opierał na Arystotelesie, tymczasem Galileusz twierdził, że językiem przyrody jest matematyka. Na bazie współczesnej fizyki, która odparła mechanicyzm i materializm w mechanice kwantowej, rozwija się biologia, której filozofia bywa nadal interpretowana materialistycznie. Zamierzenia Lenartowicza naprawy filozofii biologii przez powrót do Arystotelesa ignorują jednak te aspekty, które pokonała fizyka matematyczna, a których jeszcze nie zasymilowała filozofia biologii.

\section{Słowa kluczowe}

filozofia przyrody, matematyka, fizyka, biologia, chaos

\section{Wprowadzenie}

Filozofia, którą uprawiał Piotr Lenartowicz SJ (1934-2017), była skupiona na biologii (Grzebień 1996; Darowski 2001). Wokó1 tej nauki koncentrowały się też inne, mniej lub bardziej istotne wątki (np. duszpasterskie), których dotykał krakowski myśliciel. W naszej pracy skupimy się na tych aspektach refleksji jezuickiego filozofa przyrody, która była mu najbliższa, i jednocześnie już z naszej perspektywy - miała związek $\mathrm{z}$ naukami matematycznymi. Takie ujęcie pozwoli na zrozumienie dokonań, ale i zasadniczych kłopotów tych filozofii (nie tylko Lenartowicza), które za przedmiot swych dociekań obierają przyrodę bez istotnego uwzględnienia matematycznych zasad.

Zastanowimy się na początku, co sprawiło, że nauki przyrodnicze - a więc i biologia - mogły zacząć się tak dynamicznie w ogóle rozwijać. Na tym tle stanie się jasne, jaki typ przyrodoznawstwa skazany jest na epistemologiczne ograniczenia, by nie powiedzieć - zastój czy upadek. Z kolei przyjrzymy się znaczeniu historycznych reinterpretacji współczesnej nauki - tej dokonanej przez krakowskiego jezuitę i tej dokonywanej w ramach nauk matematycznych. W końcu pokażemy, jak braki logiczno-matematycznej metodologii wpływaja na szerzenie się redukcjonizmu typu materialistycznego, typowego dla filozofii przyrody „w starożytnym stylu” - materializmu, z którym próbował walczyć Lenartowicz. Redukcjonizm ten jest ciągle obecny w filozofii przyrody, nie tylko biologii, i od jego "mitologii" nie łatwo się uwolnić. Ze względu na znaczenie światopoglądowe, materializm ten jest także i dziś niebezpieczny etycznie, czego świadom był krakowski jezuita. 
Zastanowimy się zatem w końcu, czy ścieżka, którą obrał, może nadal być rozwijana przez innych myślicieli.

\section{Skąd biorą się sukcesy współczesnej biologii?}

Życie i jego bogactwo, odkrywane przez współczesną biologię, stanowią jakby niekończący się przedmiot badań obfitujących we wciąż nowe, zaskakujące metody dochodzenia do prawdy. Odkrycia epistemologiczne związane z nowoczesną biologią nie byłyby jednak możliwe, gdyby wcześniej nie dokonał się rozwój matematycznego przyrodoznawstwa, którego program badawczy zapoczątkował Galileusz (1564-1642) zdający sobie po raz pierwszy tak wyraźnie sprawę z tego, że przyroda "mówi” językiem matematyki; dodajmy od siebie - cała przyroda podlega logosowi matematycznemu. Dalsze sukcesy nowej fizyki, dokonywane przez Izaaka Newtona (1642-1726/7) i jego następców, nie tylko potwierdziły poprawność metodologiczną matematycznego ujmowania przyrody (science), ale zapoczątkowały nowy sposób rozwoju filozofii przyrody i matematyki. Będzie okazja niejeden raz powołać się na ten filozoficzny kamień milowy postawiony przez Galileusza (por. Pedersen 1992).

Dzięki fizyce rozwinęła się poprawna metodologia chemii, którą dziś ujmujemy jako niezwykle bogatą eksplorację jedynie wąskiego fragmentu fizyki - mechaniki kwantowej. Później rozkwitła także metodologia chemii organicznej, którą dziś ujmujemy jako niezwykle bogatą gałąź maleńkiego fragmentu chemii ogólnej, w której zasadniczą rolę pełni podstawowy pierwiastek węgiel i jego kwantowe charakterystyki. Ewolucja nowoczesnego przyrodoznawstwa opartego na fizyce matematycznej zapoczątkowała także zmianę cywilizacyjną, technologiczną, dla której klimat filozofii chrześcijańskiej stanowił unikalną bazę rozwojową. Średniowieczne odkrycie zagrożonej zapomnieniem filozofii greckiej, ożywienie jej oraz istotne przeorientowanie dokonane przede wszystkim przez św. Tomasza z Akwinu (ok. 1225-1323) pozwoliły odkryć nową harmonię między racjonalnością, religią i innymi sferami życia zrównoważonymi rozwojowo w duchu chrześcijańskiej miłości, gdzie siła argumentu racjonalnego jest większa niż nienawistna siła zbrojnego oręża czy władzy tyrana (por. np. Jan Paweł II 2005: 16n ).

Nowoczesna biologia jest nie do pomyślenia bez tej naukowej bazy, którą przyniosło chrześcijaństwo i rozwijająca się w nim fizyka matematyczna. To ona pozwala konstruować wciąż nowe przyrządy badawcze otwierające przed biologią jakby niekończące się perspektywy metodyczne, których bogactwo może być ujmowane na wiele sposobów, nie stroniąc - niestety - także od tych barbarzyńskich, wykorzystujących biologię do niesienia śmierci, cofającej jej bogatą i wciąż daleką od satysfakcjonującego ujęcia metodologię do metod $\mathrm{z}$ okresu pogaństwa, a nawet mitu. Najlepsze środowisko może zostać zanieczyszczone, także to duchowe, gdy nie dba się metodycznie o jego naturalną czystość.

\section{Lenartowicza filozoficzne inspiracje i mechanicyzm}

Piotr Lenartowicz, utalentowany lekarz, biolog i filozof, zetknął się z biologią właśnie tak dynamicznie rozwijającą się, i tak metodologicznie „profanowaną" przez sprowadzanie jej do ateistycznego materializmu. Dla katolickiego księdza i miłośnika przyrody, a także skrupulatnego badacza, sytuacja ta wymagała zdecydowanego działania. Po spirali dziejów chciał - jak to bywa w muzyce, gdzie wszystko zaczyna się "od Bacha” wrócić do Arystotelesa (384-322), który jako pierwszy filozof ujął podstawy biologiczne w systematyczny sposób. Ambitny ksiądz chciał „odkręcić” spiralę ateistycznych i materialistycznych błędów, tak obecną w nauce zawłaszczonej przez ideologie typu niemieckiego nazizmu i sowieckiego komunizmu (por. Koszteyn, Lenartowicz 1997; Lenartowicz 2014: 445n).

Lenartowicz sądził, że uda się przerzucić filozoficzny most spinający starożytność i współczesność nauki. Niestety, nie 
jest to jednak możliwe na drodze, którą obrał, gdyż cofając się, by tak rzec „przed Galileusza", fizyka - a z nią całe przyrodoznawstwo - wkracza w obszar nie do końca odmitologizowany. Demitologizacja Arystotelesa, dokonana przez św. Tomasza, odbyła się w obszarze teologii i częściowo filozofii ogólnej, i tylko fragmentarycznie w filozofii przyrody, którą Akwinata nie był pierwszorzędnie zainteresowany, gdyż „bytowość" w przyrodzie jest najsłabsza - bytami, substancjami itd. są bardziej osoby, a istotnie - Bóg. Superweniencyjne oddziaływanie teologiczne wewnątrz chrześcijaństwa sprawiło, że dopiero po kilku stuleciach Galileuszowskie przyrodoznawstwo matematyczne mogło skłonić filozofię przyrody do dalszej demitologizacji pojęć, co zresztą dokonuje się bardzo opornie aż po dzień dzisiejszy na skutek różnych uproszczeń i redukcjonizmów filozoficzno-etycznych. Widać to znowu wyraźniej w biologii, gdzie nowe i masowe odkrycia wciąż uciekają się do materialistycznego, najbardziej metodologicznie niedojrzałego tłumaczenia filozoficznego, które fizyka przeżywała wcześniej, gdy nie zdawała sobie sprawy z roli matematyki w filozofii przyrody.

Newtonowska fizyka, nie bez trudu dokonała postępu w demitologizacji filozofii przyrody m.in. właśnie dzięki matematyce. Wystarczy, ze względu na ograniczoność miejsca i przedmiot analizy, wskazać tu pojęcie np. „masy”, które całkowicie wyeliminowało pojęcie nieodmitologizowanej do końca „materii”. W fizyce współczesnej starożytne pojęcie "materii”, a tym bardziej „materii pierwszej”, nie jest do niczego potrzebne ${ }^{1}$. Znika więc metodologiczny problem całego materializmu. Co więcej, racjonalne zasady matematyczne wskazują na „nowy” sposób podejścia do przyczynowości w przyrodzie: już „siła” (ta z drugiego prawa Newtonowskiej mechaniki) jest formalną przyczyną matematyczną, w której całko-

1 Ostatnio byliśmy świadkiem spektakularnego eksperymentu odkrycia bozonu Higgsa w polu kwantowym, które „nadaje masę” cząstkom elementarnym (zob. np. Cern Courier: 2013). wicie brak jakiegokolwiek materializmu. Oczywiście dopiero refleksja metodologiczna ostatnich lat pozwoliła na „oczyszczenie" filozoficznych naleciałości (by nie powiedzieć mitycznych pozostałości) fizyki Arystotelesowskiej, w której przyczyny materialne są „tłumaczące” (choć dopuszczają i inne przyczynowanie, które sprytnie udaje się pozornie „obchodzić”); w obrębie takiej metodologii łatwo popaść (choćby przez minimalizm założeń typu Ockhamowskiego) w „czysty materializm”.

Największy sukces Newtona, matematyczne zrozumienie grawitacji, zdawało się jednak tę „matematyczną przyczynowość" przesłaniać przez to, że „masę”, wykorzystując starożytne pojęcia, interpretowano jako „ilość materii”, a siła grawitacji zależy właśnie od mas. Dopiero Einsteinowska ogólna teoria względności pozwoliła w gruncie rzeczy „retrospektywnie” zrozumieć Newtonowską fizykę, a także inne teorie pola, m.in. dzięki matematycznemu formalizmowi opracowanemu przez Élie Cartana (1869-1951). Co więcej, już w czasie sporu „Newton-Leibniz” okazało się, że Newtonowskie ujmowanie matematycznej fizyki jest sprzeczne z filozofią Newtonowską i rację miało Leibnizowskie podejście wywodzące się od kogoś, kto nie pochodził z filozoficznego kręgu odkrywcy mechaniki klasycznej. Newton sądził, że jego teoria zawiera np. absolutną przestrzeń, co jest sprzeczne z „mocą równań” Newtonowskiej fizyki. Tego typu „filozoficzny autorytaryzm" spowodował, że relatywistyczne podejście Leibnizowskie, które poprawnie interpretuje matematyczność równań Newtonowskich, zostało zapomniane aż do czasów Einsteina. Newton i wielu jego filozoficznych następców, przekuwających nowe idee przyrodnicze „przez powrót" do nieodmitologizowanej do końca filozofii starożytnej, nie zauważyli, że matematyczna teoria fizyczna jest "mądrzejsza” niż filozofia Arystotelesa. Tak zrodził się mechanicyzm - materialistyczna filozofia iluzorycznie oparta na nowej, matematycznej fizyce. Było to o tyle dziwne filozofowanie, że pole grawitacyjne jest w oczywisty 
sposób relacyjne i dotyczy wszystkich mas „naraz” , tworząc „układ” - całość racjonalnie uporządkowaną, z bezwzględnie precyzyjnymi zasadami (formami) zachowania energii, pędu, krętu itd., których nie sposób wyjaśnić przyczynami materialnymi. Układ Słoneczny po raz pierwszy został ujęty i zrozumiany jako całość matematycznych oddziaływań i to do tego stopnia, że "niezgodność” obserwacji zmysłowej i racjonalnej teorii pozwalała odkrywać nowe "byty” - planety, dotąd „zmysłowo” nieobserwowane, a jednak „materialnie” obecne - by wyrazić się w języku starożytnej filozofii. Umysł, dzięki matematyce, poznał coś, czego jeszcze nie było „w zmysłach”. Matematyczna racjonalność niosła ze sobą epistemologiczną moc, której nie dostrzegli filozofowie mechanicyzmu (Newton 1986: $88)^{2}$.

Lenartowicz, pomimo swych nowoczesnych doświadczeń z nauką, wszedł w myśl Arystotelesa, jednak bez koła ratunkowego metodologii współczesnej fizyki. Było to spowodowane niewątpliwie pragnieniem uwolnienia biologii od towarzyszącego jej materializmu, a krakowski filozof chciał tego dokonać od filozoficznych podstaw historycznych. Filozoficzna metoda "starożytnego stylu" Stagiryty nie mogła jednakże sama z siebie doprowadzić do sukcesu, gdyż taka fizyka, bez uznania filozoficznej doniosłości matematyki $\mathrm{w}$ zrozumieniu istoty przyrody jako takiej (całej przyrody), jest jałowa. Co więcej, Lenartowicz nie docenił czegoś, co Arystoteles „odkrył”, ale z czego nie uczynił (nie jego w tym wina jako pioniera) wystarczającego użytku, mianowicie przeoczył rolę logiki, która - jak dziś to wiemy - jest fragmentem matematyki tak, jak chemia organiczna - fragmentem „węglowym” tej

2 Spór o czas i przestrzeń był najwyraźniejszy w polemice Leibniza z Clarkiem i po dziś dzień się toczy (zob. np. Gołosz 1995: 49n). Przywołujemy tutaj ten problem także dlatego, że Lenartowicz będzie tłumaczył m.in. porządek przestrzenny, czasowy itd., odbiegając od fizyki matematycznej, oczywiście tej współczesnej. „nieorganicznej” ${ }^{3}$. Zaniedbawszy logikę, a przede wszystkim matematykę, Lenartowicz pozbawił się pomostu, który z wycieczki w starożytność mógł go szczęśliwie powrócić w środowisko biologii współczesnej. Było to z niewątpliwą korzyścią syntezy, która się rysowała w konfrontacji biologii współczesnej z racjonalnością tak odległą, jak starożytna, choć wciąż jeszcze uwikłaną mitologicznie w takie kwestie jak materia, przypadek, chaos itd., które zdemitologizowała fizyka kwantowa. Zastanawiające, że krakowski filozof, sympatyk komputerów, ignorował fakt, że cała informatyka, to matematyczna logika oparta na tak skromnych podstawach, jak „zero" i „jeden”.

Krakowski jezuita uwikłał się po drodze w jeszcze jeden, tym razem współczesny „atawizm” teoriopoznawczy, jakim jest wspomniany mechanicyzm. Jest to o tyle nieszczęśliwe, że w krakowskim środowisku, w którym Lenartowicz działał, w kręgach Ośrodka Badań Interdyscyplinarnych, gdzie sam dyskutował, problem filozofii mechanistycznej był gruntownie omawiany i krytykowany ${ }^{4}$. Pozostaje tajemnicą, dlaczego Lenartowicz wolał być wierny myśleniu naznaczonemu "mechanizmami”

3 Zob. o logice np. (Lenartowicz 2014: 162, zwł. przyp. 2), jednakże docenienie choćby sylogizmów Stagiryty jest u Lenartowicza szczątkowe, a o „algebrze” logiki praktycznie nie ma poważnej mowy. Co ciekawe, w swoich Elementach teorii poznania powołuje się on na ciało Boole'owskie, ale w kontekście prawdopodobieństwa (Lenartowicz 2014: 386). Szkoda, że nie wyciągnął wniosku, jak ważne jest to ciało w ogólności, co było zresztą jakby na wyciągnięcie ręki, bo Autor pisze w tym samym kontekście o komputerze, którego funkcjonowanie logiczne jest przecież sterowane logiką Boole'owską. O rewolucji informatycznej sterowanej tak prostą logika nie będziemy się tu rozpisywać, gdyż każdy jej doświadcza na co dzień.

4 Zob. np. (Heller, Życiński 1988: passim). Oczywiście Lenartowicz nie jest mechanicystą "filozoficznym", ale jego myślenie o biologii dokonuje się w kontekście mechanicznych zegarków, pojemników, maszyn, a nie układów kwantowych. Zob. np. (Lenartowicz 2014: 291, 302, 314, 473n - przyp. 4). 
w oczywistości ${ }^{5}$ i starożytnymi ujęciami, do których odwołuje się w swojej filozofii zjawisk biologicznych odkrywanych współcześnie. Problemy dzisiejsze (kwantowo-mechaniczne, termodynamika nieliniowa itd.) są u niego w zasadzie pomijane. A to właśnie one są przyrodniczym rozwiązaniem aporii materializmu i mechanicyzmu, bez uciekania się do Stagiryty. Matematyczna teoria fizyczna, jaką jest mechanika kwantowa, zdyskredytowała nieodwołalnie materializm i mechanicyzm (Heller, Życiński 1988).

\section{Witalistyczne interpretacje układów fizycznych}

Lenartowicz zachwycał się oczywistością w określaniu biologicznej całości organizmu. Fascynował się symmorfią, synheksją, stechiometrią, syntopią, synchronią i innymi cechami "materii” porządkowanej przez „duszę”. Przyjmując materialną terminologię starożytną, którą łączył z mechanistycznym obrazem biologicznych całości: kulek, prętów przenoszących oddziaływania itp., walczył z „chaosem”, „przypadkiem” itd., gdyż pojęcia te, ujmowane w starożytnym stylu, istotnie nie zostały tam zdemitologizowane ${ }^{7}$. Dziedzicząc zatem starożytne

5 Mikroukłady nie skalują się przez „rozciąganie" mikro do skali zjawisk dostępnych nam zmysłowo, uświadamianych empirycznie; atomy to nie są małe kulki; wiązania chemiczne to nie są maleńkie pręciki między kulkami itd.

6 Zob. (Lenartowicz 2014: 541). Oczywiście jest to struktura maszynowa, którą Autor aplikuje do organizmu żywego, „odkrywając” dynamicznie niepodzielną całość. Pełniejsza krytyka podobnych zabiegów w biologii została omówiona w (Dyduch-Falniowska 1988: 57-62).

7 Zob. (Lenartowicz, Ziemiański 1979: 54n). Mówiąc o chaosie i nieporządku, powołując się na „brzytwę Ockhama”, Autorzy pozostają w zdroworozsądkowej koncepcji "materialnego losowania” jakby kulek w totolotku. Nie znajdziemy tu śladu matematycznej teorii prawdopodobieństwa - matematycznego „ogarnięcia” przypadku i „chaosu”. Mamy za to przejście do złożoności biochemicznej białek, bez ich kwantowo-mechanicznej struktury. Autorzy nie zauważają, że postulowana przez nich „adekwatna przyczyna porządkująca” organizm jest pojęcie przypadkowości, przez wielu tak naiwnie ujmowane i dziś w biologicznym ewolucjonizmie, Lenartowicz nie zauważa tego, co o nich powiedziało matematyczne przyrodoznawstwo (a także średniowieczni filozofowie). Próżno szukać u Lenartowicza dyskusji nad entropią, nad termodynamiką organizmu żywego, „całości” organizmu w jego fizycznym (np. termodynamicznym) otoczeniu, „układzie” itd. Probabilistyka bez matematyki staje się oczywiście filozoficznie nieokreślona (nie ma swojej miary, która nie jest zmysłowa), a Lenartowicz nie dostrzega, że w matematycznej teorii prawdopodobieństwa, o której zresztą sam pisze, nie ma już mitycznego chaosu. Matematyczne prawdopodobieństwo, obecne fundamentalnie w fizyce współczesnej (a więc i w biologii), nie opiera się na mitycznym pojęciu "chaosu”, „przypadku”, ale jest przykładem wprost z teorii miary, choć "przyrządem” pomiarowym nie jest tu ani mechaniczny zegar, ani mechaniczna miarka, jak tego życzyłby sobie mechanicyzm, często obecny w tłumaczeniach filozofa biologii (zob. Heller 200o: 34n, 46n).

W układach fizycznych, w których organizm żywy jest tylko fragmentem całości, Lenartowicz nie dostrzega czegoś, co dziwiło go u ateistów. Wymownym tego przykładem jest eksperyment myślowy dotyczący kogoś, kto wysiada $\mathrm{z}$ rakiety na Wenus i potyka się o okulary - zapytany nie chce uznać, że wytworzył je byt rozumny, ale twierdzi, że są one wynikiem ewolucji przypadkowo sterującej materią tak, że okulary powstały podobnie jak oczy owada - przez przypadek ${ }^{8}$.

czymś „obok” chaosu - nie jest zasadą, formą substancjalną, choć domyślamy się, że życzyliby sobie, aby to była "dusza”. Arystoteles - w przeciwieństwie do Talesa - wiedział, że magnes nie ma duszy, a przecież w jego otoczeniu „materia się porządkuje". To, o czym zdają się myśleć Autorzy, to raczej "przyczyny ukryte", a nie „zasady” (formy).

8 Zob. (Lenartowicz 2014: 380n). W (Lenartowicz 1994) widzimy cały impet, z jakim Autor mierzy się z „probabilistyką”. Oczywiście nie znajdziemy nigdzie refleksji nad zasadą nieoznaczoności i prawdopodobieństwem kwantowomechanicznym, a przecież biologia w skali mikro jest opisywana 
Zauważmy jednak, że tak ewolucjonista, jak i jego oponent interpretują "przypadkowość” w przyrodzie (biologii) w duchu starożytnych przyczyn materialnych, a "chaos" jako mityczny „nieporządek”, pomijając całą współczesną matematyczną fizykę, w której nie ma mitycznego chaosu (nieujmowanego matematyczną formą). Biologia interpretowana "naukowo" mechanistycznie i filozoficznie w starożytnym, Arystotelesowskim stylu, może być skuteczna jedynie lokalnie - tam, gdzie mechanizmy lub złożenie materia-forma funkcjonuje $\mathrm{z}$ „oczywistym” przybliżeniem (np. gdzie $\mathrm{H}_{2} \mathrm{O}$ można przedstawić jako kulki z pręcikami: $\mathrm{H}-\mathrm{O}-\mathrm{H}$ ). Nie trzeba dodawać, że w ogromie nieliniowych zależności oddziaływań w przyrodzie takie przykłady są nieliczne (Dyduch-Falniowska 1988).

\section{Rekonstrukcja historyczna i jej wartość}

Można by zapytać: Czy „karkołomne” zabiegi Lenartowicza (a także Ziemiańskiego), jego intuicja powrotu do Arystotelesa były całkiem mylące? Wydawać by się mogło, że tak, że przedstawione wyżej trudności dyskredytują historyczne „rekonstrukcje” filozoficzne w naukach przyrodniczych. Tak jednak nie jest. Pomysł Lenartowicza należy ocenić zdecydowanie pozytywnie, choć trzeba go uznać za niedokończony, ale możliwy do dopracowania w myśl tego, co ukażemy poniżej. Trzeba zauważyć, że krakowski filozof wybrał się na wyprawę bez właściwego narzędzia, więc nie tylko nie potrafił dokopać się do ukrytych głęboko historycznych „skamielin”, lecz także te, które sprowadził do „muzeum”, nie były odpowiednio zabalsamowane, więc się rozpadły. Zobaczmy zatem, jak podobnego zabiegu „rekonstrukcji” z powodzeniem dokonują inni ${ }^{9}$.

właśnie taką „nieoczywistą” teorią rządzoną liczbami zespolonymi.

9 Doskonały podręcznik nowoczesnego wprowadzenia do mechaniki klasycznej (sic!), który tu przytaczamy, rozpoczyna się właśnie „od Arystotelesa”. Ta mistrzowska dydaktyka pozwala nie tylko zrozumieć starożytną filozofię, lecz także - co naj-
W fizyce matematycznej idea historycznej stylizacji pełni bardzo ważną funkcję pozwala ująć problematyczność dawnego myślenia i odsłonić jego braki. Taki zabieg pozwala dostrzec "filozofię w nauce" i oddzielić ją od mitologicznych, nieracjonalnych plew. Jest to możliwe dzięki odpowiednim narzędziom - stylizującej strukturze matematycznej. Co więcej, zabieg ten jest skuteczny nie tylko do bliskich czasowo "przodków” teorii, lecz także do nawet odległych historycznie quasi-mitycznych koncepcji. Wystarczy tu podać „rekonstrukcje" czasoprzestrzeni Galileuszowskiej i Arystotelesowskiej, przedstawionych w matematyce Cartanowskiej. W czasoprzestrzeni Galileuszowskiej można tak dobrać strukturę matematyczną, że wyraża ona czas i przestrzeń mechaniki Newtonowskiej oraz porównać wnioski filozofa z wnioskami płynącymi z matematycznego modelu. Tak odkryjemy zadziwiający epistemologiczne fakt, że równania Newtonowskie są „mądrzejsze” od Newtonowskiej filozofii.

Zauważmy przy tym, czego dokonuje tu interpretator: wyraża matematycznie to, co zawiera filozoficzna koncepcja, której na pierwszy rzut oka „oczywiście” nie widać w formalnym podejściu. Nie należy zatem winić Lenartowicza, że przeoczył to w swojej „pionierskiej” próbie takiego oczyszczenia teorii Arystotelesa, aby współczesny biolog przestał być materialistą (na skutek filozoficznego wywodu). Jednak - zauważmy - Lenartowicz nie miał (nie wykorzystał) niematerialnego narzędzia matematycznego, aby przerzucić ten pojęciowy most, a które posiada dzisiejsze matematyczne przyrodoznawstwo, pozwalające stylizować np. czasoprzestrzeń Arystotelesowską jako iloczyn kartezjański czasu i przestrzeni. Takie postępowanie, nieznane Arystotelesowi (czy wyżej - Galileuszowi) jest jednak poprawnym ujęciem „lokalnej filozofii” Stagiryty przez

ważniejsze - pozwala „wrócić” do teraźniejszości (zob. Ingarden, Jamiołkowski 1980: 9-40). Następny rozdział to wariacje nt. demitologizacji „materii” przez współczesną fizykę matematyczną (Ingarden, Jamiołkowski 1980: 41-67). 
współczesnych fizyków matematycznych wystylizowaniem dawnego „modelu”, zgodnego z dawną filozofią, który „zapisaliby” dawni myśliciele, sądząc, że nie popełniają błędu metodologicznego. Takie postępowanie jest więc bardzo owocne epistemologicznie - pozwala zrozumieć dzisiejszemu przyrodnikowi trudności "dawnych fizyk" i tego, co lokalnie ujmowały one poprawnie, albo czego nie dało się ująć ze względu na mitologiczne, nieracjonalne konotacje. Tak można by zobaczyć, że „materia” i „masa”, „przypadkowość” i „matematyczne prawdopodobieństwo" mają zupełnie odmienne znaczenia: mityczne i filozoficzne.

Właśnie na bazie Arystotelesowskiej absolutnej przestrzeni i absolutnego czasu możliwa okazała się matematyczna stylizacja, której choć nie dokonał sam autor, Arystoteles, gdyż nie znał współczesnych nam pojęć, za co nikt nie czyni mu z tego powodu żadnego zarzutu - to można ten dzisiejszy model nazwać jego imieniem. Podobnie, czasoprzestrzeni Galileuszowskiej nie opracował Galileusz, ale wymodelowali ją dzisiejsi uczeni, nadając jej imię zgodne z filozofią Galileuszowską. Takie postępowanie dzisiejszych uczonych poprawnie "przerzuca” historyczny most pomiędzy ideami, choć samo postępowanie wymaga właściwego komentarza „filozofii w nauce”, który ma znaczenie historycznie nieistotne ze względu na dzisiejszy, prawdziwszy dostęp do rzeczywistości przyrodniczej dzięki matematyce.

Co więcej, w takiej stylizacji dawnych filozofii można przeprowadzić poprawne rozumowania prowadzące oczywiście do niefizycznych i absurdalnych (dla nas, globalnie) wniosków - np. że w czasoprzestrzeni Arystotelesa można mierzyć odległość między nierównoczesnymi zdarzeniami. Nie budzi wątpliwości, że Arystoteles nie uznałby dziś takiego absurdu „swojej” czasoprzestrzeni, podobnie jak $\mathrm{Ne}$ wton nie uznałby w swej filozofii przestrzeni absolutnej, gdyż stylizacja czasoprzestrzeni Galileuszowskiej ma jedynie absolutny czas, a przestrzeń jest tu wyraźnie względna i w takiej, chwilowej przestrzeni wyznacza się odległość - między zdarzeniami równoczesnymi. Dzięki takim stylizacjom jest więc widoczny metodologiczny postęp w filozofii czasu i przestrzeni od Arystotelesa do $\mathrm{Ne}$ wtona. Zrozumiałe staje się relatywistyczne przejście do czasoprzestrzeni Minkowskiego i do ogólnej teorii względności. Dostrzegając granice epistemologiczne u dawnych filozofów, jesteśmy im jednak wdzięczni za to, że wydostali się z ciemności mitycznych interpretacji, dzięki czemu inni mieli łatwiejszy start do dalszych, racjonalnych dociekań.

Gdyby Lenartowicza filozofia przyrody dysponowała podobnym, matematycznym narzędziem, próba stylizacji starożytnej biologii mogłaby być (myśląc analogicznie) podobnie doniosła. Jednakże dla biologii takiej stylizacji jeszcze nie dokonano, a filozofowie biologii, zadowalając się naiwnymi tłumaczeniami materialistycznymi lub ewolucjonistyczną przypadkowością, a więc - choć z intencjami przeciwnymi do Lenartowicza - nadal ujmują współczesną biologię „w starożytnym stylu” - bez zagłębiania się w matematyczność przyrody i jej osiągnięcia. Biologowie-materialiści popełniają więc ten sam błąd, który zrobił Lenartowicz, tylko że intencje ich są odwrotne - oni wybierają chaos i materializm, a Lenartowicz chciał od tego uciec przez cofanie się do zarania dziejów, do tworzenia się pojęcia „materii” i „przypadku”. Jednakże przed filozofią była u Greków mitologia, więc „dokopać się" do głębszej racjonalności nie można było; wiadomo przy tym, że „kopać” gdzie indziej też nie ma sensu, chyba że straciliśmy historyczny kontakt z jakąś racjonalną cywilizacją.

Współczesna fizyka pokazuje, że obie drogi powoływania się na filozoficzne idee w starożytnym stylu bez logiczno-matematycznego pomostu są niepoprawne i niepotrzebne. W uprawianiu zaś biologii i jej filozofii zgodnie ze współczesnym, matematycznym przyrodoznawstwem nie grozi nam żaden starożytny materializm ani mityczny chaos. W uprawianiu ich natomiast bez etyki - grozi nam broń biologiczna 
i samounicestwienie, przed czym skutecznie przestrzegałby nas dziś św. Tomasz.

Jak pokazuje historia Higgsowskiego pola, możemy oczekiwać coraz bardziej racjonalnego ujęcia samej fizyki, w duchu zasad matematycznych wyznaczonych kamieniem milowym postawionym przez Galileusza: metodą matematycznego przyrodoznawstwa stawiającego falsyfikowalne logicznie hipotezy, które są potwierdzane ilościowo przez coraz to doskonalsze pomiary. Niewątpliwie skorzysta na tym także biologia i jej filozofia.

\section{Podsumowanie}

Filozofia Lenartowicza, której uprawianie ma przejrzysty i etycznie doniosły cel, zanurzyła się w starożytność z intencją usunięcia błędów filozoficznych. Zagłębiając się w historię, bez narzędzi logiczno-matematycznych, myśl krakowskiego myśliciela (i jego współpracowników, m.in. wspomnianego już Ziemiańskiego) przejęła niepostrzeżenie starożytny rys dogmatyzmu. Niewyposażona w metody logicznego wnioskowania, nie mówiąc już o uznawaniu praw matematycznych, myśl ta nie posiada czegoś na kształt choćby bogatej „algebry”, przez co stała się mniej lub bardziej uporządkowanym zbiorem życzeń, postulatów, quasi-aksjomatów deklaratywnych, by nie powiedzieć dogmatycznych, jak to bywało właśnie w starożytności. Gdyby Lenartowicz dysponował właściwym aparatem typu logicznego, można by w tym znaleźć obecną przynajmniej metodę hipotetyczno-dedukcyjną, logikę falsyfikacji itd., ale właśnie tego wyraźnie brak w jego filozofii. Nawet trafne „aksjomaty”, bez możliwości formułowania twierdzeń, pozostają zhermetyzowane, a niemożność postawienia następnego kroku „bez autorytetu mistrza” sprawia, że nie rozwija się żadna szkoła. Tak też się stało z filozofią Lenartowicza, który nie wychował uczniów. Jego filozoficzne "aksjomaty” są jak starożytny posąg statycznej, zdeklarowanej „oczywistości” niematematycznej myśli. Dokładnie pięć lat po śmierci księdza Lenartowicza, Akademia Ignatianum zlikwidowała, nie bez słusznych protestów, „filozofię przyrody” w nazwach katedr, poświęcając mu jednocześnie część otrzymanego grantu. Można mieć nadzieję, że opisane przez niego jako "fakty” biologiczne problemy, wystylizowane na sposób Arystotelesowski, uda się kiedyś sformalizować tak, że staną się możliwe do logicznych analiz, np. przez sztuczną inteligencję.

Do tego, by tłumaczyć selekcję, synchronię itd. wystarczy znać zasady matematyczne. „Selekcja” poziomów energetycznych $\mathrm{w}$ atomach jest potwierdzana empirycznie z niespotykaną dokładnością. Teoretyczna selektywność kwadratu odległości w Newtonowskiej sile grawitacyjnej jest „nieskończona" $\left(F=m M / r^{2}\right.$, a nie $\left.F=m M / r^{1.99}\right)$, gdyż tylko takie orbity są zamknięte, a to właśnie jest „oczywiste”. Ruch planet dokonuje się w idealnej płaszczyźnie, bo jest to związane z zasadą zachowania krętu, a regularność tych ruchów jest precyzyjnie zgodna z „duchowymi” prawami matematyki. Robienie "niematematycznej” filozofii z tego, jak planeta „selekcjonuje” ruch w płaszczyźnie, można sobie darować, bo inaczej trzeba by pytać o „dusze” Układu Słonecznego, Atomu Węgla itp. Nie ma potrzeby stawiać tez-pytań jak to czynili w swojej publikacji Lenartowicz i Ziemiański (Lenartowicz, Ziemiański 1979).

W końcu można sobie postawić inne pytanie: dlaczego właśnie biologia miałaby być wyróżniona w dochodzeniu do metafizyki? Gdyby tak było, to trzeba by uznać, że biologia powinna też wskazać, że inne nauki do metafizyki dojść nie mogą tak jak ona (jak np. matematyka i jej teoria prawdopodobieństwa). To jednak implikuje, że z biologii powinno wynikać: (1) tak dochodzenie do istoty rzeczy, jak i (2) odmowa w jego dochodzeniu, np. matematyce. Czyli, że odmawiając matematyce sposobu dochodzenia do metafizyki, biologia powinna przestać być matematyczna, a tak oczywiście nie jest, gdyż kod genetyczny (by użyć czegoś ewidentnego) jest zapisany matematycznie i jest czymś istotnym w biologii. Należy zatem uznać, że biologia nie jest w żaden sposób wyróżniona przez filozofię przyrody - jest 
tak samo ważna jak chemia organiczna i nieorganiczna, jest tak samo ważna jak fizyka. Biologia i inne nauki przyrodnicze są częścią jednej Fizyki. Tu się wszyscy zgodzą z Arystotelesem. Zgodzimy się też z Galileuszem, że językiem [całej] przyrody jest matematyka, bez względu na przedmiot szczegółowych zainteresowań.

\section{Bibliografia}

Cern C., 2013, Birth of a Higgs boson. Results from ATLAS and CMS now provide enough evidence to identify the new particle of 2012 as 'a Higgs boson', International Journal of High-Energy Physics, April 26th, [http://cerncourier.com/cws/article/ cern/53086].

Darowski R., 2001, Filozofia jezuitów w Polsce w XX wieku. Próba syntezy - stownik autorów, Wyższa Szkoła Filozoficzno-Pedagogiczna Ignatianum, Kraków.

Dyduch-Falniowska A., 1988, Poczatek drogi, Zagadnienia Filozoficzne w Nauce, t. 10, 57-62.

Gołosz J., 1995, Czas i przestrzeń a świat fizyczny, Zagadnienia Filozoficzne w Przyrodzie, t. 17, 49-61.

Heller M., Życiński J., 1988, Wszechświat - maszyna czy myśl?, Polskie Towarzystwo Teologiczne, Kraków.
Heller M., 200o, Czy Kosmos jest chaosem?, Zagadnienia Filozoficzne w Nauce, t. 27, 33-47.

Koszteyn J., Lenartowicz P., 1997, Czy wspótczesna nauka mówi o Bogu?, w: Kijas Z. (red.) Mówić o Bogu [...], Wyd. „Bratni Zew”, Kraków, 89-114. Grzebień L. i in. (red.), 1996, Encyklopedia wiedzy o jezuitach na ziemiach Polski i Litwy, 1564-1995, Wydział Filozoficzny Towarzystwa Jezusowego, Kraków.

Ingarden R.S., Jamiołkowski A., 1980, Mechanika klasyczna, Państwowe Wydawnictwo Naukowe, Warszawa - Poznań.

Newton I., 1986, Scholium, Zagadnienia Filozoficzne w Nauce, t. 8, 88-98.

Jan Paweł II, 2005, Pamięć i tożsamość, Wyd. Znak, Kraków.

Lenartowicz P., Ziemiański S., 1979, Aspekt porzadku wzjawiskach życiowych, Zagadnienia Filozoficzne w Nauce, t. 1, 54-65.

Lenartowicz P, 1994, O „cudach” probabilistycznych, czyli fakt selekcji i odmowa poznania tego faktu, Rocznik Wydziału Filozoficznego Towarzystwa Jezusowego w Krakowie, t. 5, 99-147.

Lenartowicz P., 2014, Elementy teorii poznania, Wydawnictwo WAM - Akademia Ignatianum, Kraków.

Pedersen O., 1992, Księga Natury, Zagadnienia Filozoficzne w Nauce, t. 14, 19-50.

\section{Piotr Lenartowicz's Philosophy and Mathematical Science}

This article discusses Piotr Lenartowicz's S.J., philosophy of nature in the context of mathematical natural sciences. Lenartowicz based his philosophical reflections on biology on the thinking of Aristotle and not on Galileo's assumption that mathematics is the language of nature. On the basis of modern physics, which has refuted mechanicism and materialism in quantum mechanics, biology develops, but its philosophy can be still interpreted materialistically. Lenartowicz's intention was to repair the philosophy of biology by returning to Aristotle. However, it ignores the aspects that mathematical physics has overcome, aspects which have not yet been assimilated by the philosophy of biology.

\section{Keywords}

philosophy of nature, mathematics, physics, biology, chaos 